\title{
INNOVATION OF HIGH NUTRITIONAL VALUE SNACK BARS FROM DATES AND EXTRUDED CEREALS
}

\author{
HANAN A. HUSSIEN, EMAN M. SALEM AND M.R. MASOUD
}

Food Technology Research Institute, ARC, Cairo, Egypt

(Manuscript received 31 October 2017)

\begin{abstract}
I n Egypt, dates are considered a strategic crop. Egypt occupies the first place in the world in date production, with annual production about 1.5 million tons. Dates are known for their high concentrations of sugars. An attempt was made to produce a product, from nationally available materials, with enhanced nutritional value and acceptability for consumers. This study, aimed to produce novel date bar by using date, date syrup, sesame seeds, extruded whole wheat, extruded hull-less barley, extruded wheatbarley, wheat-rice mixtures, pop-corn and a mixture of all. In this study, products were prepared with no sugar additives, since dates and date syrup are rich in natural sugars. Various analysis (proximate composition and sensory evaluation) were performed. Results showed that date fruit bars were rich in protein, fat and carbohydrates with good energy values. Texture wise, products were easy to bite and chew. Results of sensory quality evaluation indicated that dates, date syrup and puffed cereals have excellent potential to be converted into snack bars. Results generated in this study show that date-based fruit bars may be expected to fulfill some the requirements of health-conscious consumers. It is anticipated that this product will attract both children and adults.
\end{abstract}

Key words: Date, Healthy date bars, Hull-less barley, Whole wheat, Sesame seeds, Pop-corn, Wheat-rice extrudets.

\section{INTRODUCTION}

Fruit bars can be an exceptional instant food that can deliver the required dietary fiber and other bioactive compounds, required to meet the daily requirements in humans (Sun-Waterhouse et al., 2010).

The date palm is one of the oldest fruit trees in the Arabian Peninsula and has played an important role in the day-to-day life of the people of this region for the last 7000 years-Dates are known to be rich in carbohydrates (80\%) but quite low in protein $(2-3 \%)$. The flesh of dates has always played an essential role in the diet of the local inhabitant of the Arab countries. Studies conducted on the composition of the date flesh (Ghnimi et al., 2017). Though date fruits have high economical value, one of the major concerns for growers is the loss of freshly harvested dates during picking, storage, and processing stages (Moawadand Al-Ghamdi, 2013). These damaged date fruits do not possess any demand or market value owing to their non-desirable texture (either they are too soft or too hard). Hence, in majority of the cases, the damaged fruits are 
preferred mainly as a live-stock feed. Fruit bars can be a better alternative to direct consumption of dates, especially during off-seasons. In addition, date based fruit bars can meet the increased demands of local and international consumers where this fruit is not grown. Sharifi et al., 2017 studied several varieties of dates and reported that they were good sources of minerals, especially potassium (430-774.71 mg/100gm), calcium (11-36 mg/100gm) and iron (1.5-5.2 mg/100gm).

Barley grains are a good source of both soluble and insoluble dietary fiber with clinically demonstrated health benefits such as attenuation of postprandial glycemic and lowered cholesterol levels (Symons and Brennan 2004). Gadade et al., 2017 reported the chemical composition of sesame shows that the seed is an important source of oil (44-58\%), protein (18-25\%), carbohydrate ( 13.5\%) and ash ( $5 \%)$.

In this study, we aimed to produce novel date bar by using date, date syrup, sesame seeds, extruded whole wheat, extruded hull-less barley, extruded wheatbarley, wheat-rice mixtures, pop-corn and a mixture of all. In this study, products were prepared with no sugar additives

\section{MATERIALS AND METHODS}

\subsection{Materials}

Date, wheat, corn, rice, sesame seeds and barley were obtained from the Giza local market. Chemicals were analytical grade, were obtained from El Gomhoria for chemical Company Egypt.

\subsection{Syrup Preparation}

Syrup was produced according to the method of Al-Farsi (2003). Briefly, dates were extracted twice with water $(1: 1)$ at $60{ }^{\circ} \mathrm{C}$ and then filtered through a Whatman no. 41 filter paper. Clear juice was concentrated to $72^{\circ}$ Brix using rotary evaporator at $70^{\circ} \mathrm{C}$. Finally, syrup were obtained.

\subsection{Cereal Preparation}

Wheat, corn, rice and barley were milled in a laboratory mill (Brabender Automat Mill Quadrumat Senior, Germany).

\subsection{Extrusion}

All samples were processed in a single screw extruder (Brabender Model 3037, at The Arab Company for Food) with the following characteristics: inter changeable configurations and screw; control of temperature in the various heating zones, and adjustable screw speed. The following parameters were set for the temperature zones: (Zone $1=90^{\circ} \mathrm{C}$ ); Zone $2=130^{\circ} \mathrm{C}$; zone $3=200^{\circ} \mathrm{C}$ ); screw speed of $277 \mathrm{rpm}$; feeding rate of $292 \mathrm{~g} /$ minutes, and circular matrix of $3.85 \mathrm{~mm}$. 


\subsection{Production of Date Bars}

For date bars, dry ingredients were blended first followed by the date pieces and date syrup and were uniformly blended and mixed thoroughly. Mixing was done in a mixer. The mixture was formed into bars approximately $13 \times 18 \mathrm{~cm}$ and baked in a pre-heated oven at $160^{\circ} \mathrm{C}$ for 35 minutes (Aliani et al., 2011).

Table 1. Formulas for Different Date Bars

\begin{tabular}{|l|c|c|c|c|c|c|c|}
\hline $\begin{array}{l}\text { Blend } \\
\text { number }\end{array}$ & Date & $\begin{array}{c}\text { Date } \\
\text { Syrup }\end{array}$ & $\begin{array}{c}\text { Sesame } \\
\text { Seeds } \\
\text { (white) }\end{array}$ & $\begin{array}{c}\text { Extruded } \\
\text { Wheat }\end{array}$ & $\begin{array}{c}\text { Extruded } \\
\text { Necked } \\
\text { Barley }\end{array}$ & Popcorn & $\begin{array}{c}\text { Extruded } \\
\text { Rice-Wheat }\end{array}$ \\
\hline Control & 60 & 20 & 20 & - & & & \\
\hline F1 & 30 & 20 & 20 & 30 & - & - & - \\
\hline F2 & 30 & 20 & 20 & - & 30 & - & - \\
\hline F3 & 30 & 20 & 20 & 15 & 15 & - & - \\
\hline F4 & 30 & 20 & 20 & - & - & 30 & - \\
\hline F5 & 30 & 20 & 20 & - & - & - & 30 \\
\hline F6 & 30 & 20 & 20 & 7.5 & 7.0 & 7.0 & 7.5 \\
\hline
\end{tabular}

\subsection{Proximate analysis}

All raw materials and products were analyzed for moisture, protein, ash, fat and crude fiber according to the methods of AOAC, 2005. Total carbohydrate was calculated by difference. Total calories were calculated by the formula of James, 1995 as follows: Total calories $=$ Fat $\times 9+$ Protein $\times 4+$ Total carbohydrate $\times 4$

\subsection{Physical Evaluation}

Moisture analysis was conducted according to the methods of AOAC, 2005. Water activity (aw) was measured with a rotronic Hygro Lab EA10-SCS (Switzerland) aw meter. The measurements were performed in triplicate. Bar samples were crushed into small pieces and loosely placed into the plastic sample cups until the cups were approximately half full. The cups with the bar samples were then placed into the measuring chamber one at a time. Hardness and fracturability were determined by a universal testing machine (Brook field Engineering Lab. Inc., Middleboro, MA 023461031, USA).

\subsection{Sensory Evaluation}

The products were evaluated by 15 semi-trained panelists from the Food Technology Research Institute (FTRI), using a 9 point hedonic scale. A sample with a score of 5 and above was rated as good (acceptable); below a score of 5 , the product was unacceptable. Each judge was given the samples and was asked to evaluate the products for color, appearance, taste, texture, flavor and overall acceptability (Larmond, 1994). 


\subsection{Statistical Analysis}

Statistical analyses were carried out by SPSS 16 program. Data were expressed as means \pm SEM and the Statistical analysis was performed using one-way analysis of variance followed by Duncan's tests. (SPSS, 2000)

\section{RESULTS AND DISCUSSION}

\subsection{Chemical Analysis of Raw Materials}

Values for date fruit and date syrup were within the range of results published by Al-Farsi et al., 2007. Results of hull-less barley are in agreement with work by Hatcher et al, 2005. While sesame seeds results agree with work by Gadade et al., 2017 who reported the chemical composition of sesame shows that the seed is an important source of oil (44-58\%), protein (18-25\%), carbohydrate ( 13.5\%) and ash ( $5 \%)$.

Table 2. Chemical Analysis of Raw Materials

\begin{tabular}{|l|c|c|c|c|c|c|c|c|}
\hline & Date & $\begin{array}{c}\text { Date } \\
\text { Syrup }\end{array}$ & $\begin{array}{c}\text { Sesame } \\
\text { Seeds } \\
\text { (white) }\end{array}$ & $\begin{array}{c}\text { Extruded } \\
\text { Wheat }\end{array}$ & $\begin{array}{c}\text { Extruded } \\
\text { barley }\end{array}$ & $\begin{array}{c}\text { Extruded } \\
\text { Wheat- } \\
\text { Barley }\end{array}$ & $\begin{array}{c}\text { Pop- } \\
\text { corn }\end{array}$ & $\begin{array}{c}\text { Extruded } \\
\text { Wheat- } \\
\text { Rice }\end{array}$ \\
\hline Protein & 2.14 & 0.95 & 34.41 & 1 r.r. & 11.00 & 11.9. & $\wedge .00$ & $9 .$. \\
\hline Fat & 0.38 & 1.84 & 47.37 & 1.58 & $1 . \S)$ & 1. ro & 4.20 & 1.23 \\
\hline Ash & 3.67 & 0.70 & 3.76 & 0.91 & 1.21 & 1.37 & 1.20 & 0.93 \\
\hline Fiber & 8.10 & 1.25 & 9.05 & 1.82 & 2.37 & 3.5 & 2.30 & 1.62 \\
\hline Carbohydrate** & 93.81 & 96.51 & 14.46 & 85.31 & 85.88 & 85.38 & 86.60 & 88.84 \\
\hline \multicolumn{7}{|c|}{ Mineral Content (mg/100gm) } \\
\hline $\mathrm{P}$ & 40.0 & 138.01 & 774 & 331 & 474 & 352 & 300 & 225 \\
\hline $\mathrm{Ca}$ & 34.75 & 46.24 & 10.98 & 29.34 & 24.09 & 25.11 & 10 & 25.09 \\
\hline $\mathrm{K}$ & 652 & 490 & 406 & 364 & 350 & 357 & 301 & 235 \\
\hline $\mathrm{Na}$ & 3.0 & 5.95 & 39 & 5 & 4 & 4.65 & 4.00 & 4.87 \\
\hline $\mathrm{Mg}$ & 35.0 & 56.98 & 346 & 133 & 148 & 143 & 131 & 69 \\
\hline $\mathrm{Fe}$ & 3.63 & 15.05 & 3.09 & 1.84 & 1.20 & 2.43 & 2.66 & 1.76 \\
\hline $\mathrm{Zn}$ & 0.48 & 9.85 & 10.23 & 0.48 & 3.07 & 1.56 & 3.44 & 0.50 \\
\hline $\mathrm{Cu}$ & 0.29 & 0.13 & 1.46 & 0.61 & 0.34 & 0.47 & 0.42 & 0.81 \\
\hline
\end{tabular}

Values are means of three replicates $\pm \mathrm{SD}$, on dry weight basis. $* *$ Total carbohydrates were calculated by difference.

\subsection{Physical Properties of Date Bars}

Moisture content ranged between $18.50 \%$ and $19.59 \%$. The addition of cereals reduced the moisture content of the date bars. This may be due the ability of added cereals to absorb date syrup, thus decreasing the moisture. There were no significant differences $(p>0.05)$ in water activity $(0.515-0.521)$ between the cereal bars formulated with different cereals and the control, as shown in Table 3. The values for water activity were all well below 0.7 , indicating low risk of microbial proliferation and pathogenic spoilage and good shelf life (Sun-Waterhouse et al., 2010). Molds and yeasts usually start to grow at a water activity between 0.7 and 0.8 , while the bacterial growth starts to take place at water activity of 0.8 . Also, the presence of sugars and antimicrobials in cereals makes the product microbiologically safe. 
Texture is another most important property which determines the overall quality and consumer acceptability of a food product. Two texture parameters i.e. hardness (the force required to disintegrate sample) and fracturability (the extent of deformation of sample) were studied. The results of instrumental texture of the date bars are shown in Table 3. The hardness increased significantly with the addition of $30 \%$ cereals. This result may be due to addition of cereals, which have the ability of cereals to absorb date syrup, allowing the ingredients to agglomerate, and the date bars becoming more compressed.

The data (Table 3) showed that addition of cereals had significant effect on texture of bars. Maximum value of hardness was observed in bars with extruded wheat (F1) (1572.53g) and minimum in pop-corn bars (F4) (1317.11g). On the other hand, the highest value of fracturability was observed in pop-corn bars (F4) (79.60) and the lowest in extruded wheat-rice bars (F5) (76.35 mm). sIn a similar study, it was found that hardness decreased in date bars with the addition of whey protein concentrate and vetch protein isolates (Nadeem et al., 2012). However, it is worth mentioning that this difference may be due to the different formulations and methodologies used for the manufacture of the cereal bars, among other variables. Protein addition, like whey protein that has considerable viscosity, gel strength and water-holding capacity may contribute in the texture of the bars such as hardness (Nadeem et al., 2012).

Table 3. Physical Properties of Date Bars

\begin{tabular}{|l|c|c|c|c|}
\hline & Moisture & Water activity & Hardness $(\mathrm{g})$ & Fracturability (Mm) \\
\hline Control & $19.59 \pm 0.10^{\mathrm{a}}$ & $0.520 \pm 0.01$ & $1437.50 \pm 0.10$ & $77.92 \pm 0.08$ \\
\hline F1 & $18.52 \pm 0.09^{\mathrm{c}}$ & $0.518 \pm 0.04$ & $1568.91 \pm 0.12$ & $76.38 \pm 0.09$ \\
\hline F2 & $18.50 \pm 0.05^{\mathrm{c}}$ & $0.516 \pm 0.02$ & $1572.53 \pm 0.09$ & $76.35 \pm 0.13$ \\
\hline F3 & $18.55 \pm 0.02^{\mathrm{c}}$ & $0.521 \pm 0.06$ & $1570.25 \pm 0.13$ & $76.37 \pm 0.10$ \\
\hline F4 & $19.01 \pm 0.07^{\mathrm{b}}$ & $5.519 \pm 0.01$ & $1547.31 \pm 0.11$ & $76.34 \pm 0.06$ \\
\hline F5 & $19.21 \pm 0.03^{\mathrm{b}}$ & $0.517 \pm 0.03$ & $1317.11 \pm 0.10$ & $79.60 \pm 0.12$ \\
\hline F6 & $19.14 \pm 0.11^{\mathrm{b}}$ & $0.515 \pm 0.05$ & $1345.20 \pm 0.08$ & $79.21 \pm 0.09$ \\
\hline
\end{tabular}

Values are means of three replicates $\pm \mathrm{SD}$, on dry weight basis.

\subsection{Chemical Composition of Date Bars}

Dates are known for their high concentrations of sugars, an attempt was made to produce a product, from nationally available materials, with enhanced nutritional value and acceptability for consumers.

The results are presented in Table 4. The chemical composition of the date bars changed significantly with different cereal additives. In general, the addition of cereals resulted in an increase in protein, fat and energy. Bars with extruded wheat (F1) showed the highest protein content (11.42\%) which may result from the higher protein content of wheat compared with (8.6\%) for control; bars with extruded barley (F2) had the highest fiber content (5.52\%) which may be due to the higher fiber content of barley. 
Pop-corn bars (F4) showed the highest fat (11.22\%) and energy (446.67 kJ) contents which may result from the higher fat content of pop-corn. Results of bars are higher than those reported by Parn et al., 2015 who produced fruit bars from date paste.

Table 4. Chemical Composition of Date Bars

\begin{tabular}{|l|c|c|c|c|c|c|}
\hline & $\begin{array}{c}\text { Protein } \\
(\mathrm{g} / 100 \mathrm{gm})\end{array}$ & $\begin{array}{c}\text { Fat } \\
(\mathrm{g} / 100 \mathrm{gm})\end{array}$ & $\begin{array}{c}\text { Fiber } \\
(\mathrm{g} / 100 \mathrm{gm})\end{array}$ & $\begin{array}{c}\text { Ash } \\
(\mathrm{g} / 100 \mathrm{gm})\end{array}$ & $\begin{array}{c}\text { Carbohydrate(g/1 } \\
00 \mathrm{gm})\end{array}$ & $\begin{array}{c}\text { Energy } \\
(\mathrm{kJ})\end{array}$ \\
\hline Control & $8.60 \pm 0.13^{\mathrm{e}}$ & $10.07 \pm 0.11^{\mathrm{d}}$ & $6.90 \pm 0.11^{\mathrm{a}}$ & $2.90 \pm 0.03$ & $78.43 \pm 0.08$ & 438.75 \\
\hline F1 & $11.42 \pm 0.03^{\mathrm{a}}$ & $10.43 \pm 0.04^{\mathrm{b}}$ & $5.04 \pm 0.05^{\mathrm{e}}$ & $2.27 \pm 0.02^{\mathrm{c}}$ & $75.88 \pm 0.03^{\mathrm{e}}$ & $443.07^{\mathrm{b}}$ \\
\hline F2 & $11.20 \pm 0.02^{\mathrm{b}}$ & $10.38 \pm 0.09^{\mathrm{c}}$ & $5.52 \pm 0.07^{\mathrm{b}}$ & $2.36 \pm 0.05^{\mathrm{b}}$ & $76.06 \pm 0.07^{\mathrm{d}}$ & $442.30^{\mathrm{d}}$ \\
\hline F3 & $11.28 \pm 0.06^{\mathrm{b}}$ & $10.36 \pm 0.07^{\mathrm{c}}$ & $5.21 \pm 0.11^{\mathrm{c}}$ & $2.40 \pm 0.08^{\mathrm{a}}$ & $75.99 \pm 0.09^{\mathrm{de}}$ & $442.31^{\mathrm{d}}$ \\
\hline F4 & $10.25 \pm 0.09^{\mathrm{c}}$ & $10.33 \pm 0.05^{\mathrm{c}}$ & $4.50 \pm 0.03^{\mathrm{f}}$ & $2.27 \pm 0.11^{\mathrm{c}}$ & $77.19 \pm 0.11^{\mathrm{b}}$ & $442.57^{\mathrm{c}}$ \\
\hline F5 & $10.09 \pm 0.07^{\mathrm{d}}$ & $11.22 \pm 0.02^{\mathrm{a}}$ & $5.18 \pm 0.09^{\mathrm{cd}}$ & $2.35 \pm 0.03^{\mathrm{b}}$ & $76.39 \pm 0.05^{\mathrm{c}}$ & $446.67^{\mathrm{a}}$ \\
\hline F6 & $9.95 \pm 0.05^{\mathrm{e}}$ & $10.46 \pm 0.11^{\mathrm{b}}$ & $5.16 \pm 0.02^{\mathrm{d}}$ & $2.29 \pm 0.07^{\mathrm{bc}}$ & $77.33 \pm 0.09^{\mathrm{a}}$ & $443.14^{\mathrm{b}}$ \\
\hline
\end{tabular}

Values are means of three replicates $\pm \mathrm{SD}$, on dry weight basis. $* *$ Total carbohydrates were calculated by difference.

The mineral composition of the date bars changed significantly with the addition of different cereals. The results are presented in Table 4.

Bars with extruded wheat (F1) showed the highest potassium and sodium content $(496.8,3.69 \mathrm{mg} / 100 \mathrm{gm})$ which may result from the higher potassium and sodium content of wheat; bars with extruded barley (F2) had the highest phosphorus, calcium and magnesium content $(219.8,36.75$ and $93.1 \mathrm{mg} / 100 \mathrm{gm})$ which may be due to the higher phosphorus, calcium and magnesium content of barley. Pop-corn bars (F4) showed the highest iron and zinc (6.67 and $3.92 \mathrm{mg} / 100 \mathrm{gm})$ which may result from the higher iron and zinc content of pop-corn. Results of bars are higher than those reported by Al-Hotti et al., 1997 who produced date bars with almond, sesame, oat flakes and skim milk.

Table 5. Mineral Composition ( $\mathrm{mg} / 100 \mathrm{~g}$ ) of Date Bar Samples

\begin{tabular}{|l|c|c|c|c|c|c|c|c|}
\hline & \multicolumn{5}{|c|}{ Macro-elements (mg/100gm) } & \multicolumn{3}{c|}{ Micro-elements (mg/100gm) } \\
\hline & $\mathrm{P}$ & $\mathrm{Ca}$ & $\mathrm{K}$ & $\mathrm{Na}$ & $\mathrm{Mg}$ & $\mathrm{Fe}$ & $\mathrm{Zn}$ & Cu \\
\hline Control & $170.00 \pm 0.11^{\mathrm{f}}$ & $32.29 \pm 0.14^{\mathrm{a}}$ & $509.58 \pm 0.12^{\mathrm{a}}$ & $3.12 \pm 0.07^{\mathrm{d}}$ & $105.83 \pm 0.02^{\mathrm{a}}$ & $7.29 \pm 0.09^{\mathrm{a}}$ & $3.33 \pm 0.05^{\mathrm{e}}$ & $0.51 \pm 0.04^{\mathrm{a}}$ \\
\hline F1 & $215.00 \pm 0.09^{\mathrm{b}}$ & $31.12 \pm 0.02^{\mathrm{b}}$ & $496.80 \pm 0.19^{\mathrm{b}}$ & $3.69 \pm 0.03^{\mathrm{a}}$ & $90.10 \pm 0.10^{\mathrm{c}}$ & $6.50 \pm 0.03^{\mathrm{c}}$ & $4.48 \pm 0.07^{\mathrm{a}}$ & $0.46 \pm 0.09^{\mathrm{b}}$ \\
\hline F2 & $219.80 \pm 0.03^{\mathrm{a}}$ & $29.75 \pm 0.09^{\mathrm{d}}$ & $494.00 \pm 0.05^{\mathrm{c}}$ & $3.49 \pm 0.15^{\mathrm{c}}$ & $93.10 \pm 0.05^{\mathrm{b}}$ & $6.37 \pm 0.11^{\mathrm{d}}$ & $3.85 \pm 0.02^{\mathrm{c}}$ & $0.39 \pm 0.07^{\mathrm{c}}$ \\
\hline F3 & $205.50 \pm 0.07^{\mathrm{c}}$ & $30.18 \pm 0.07^{\mathrm{c}}$ & $495.40 \pm 0.09^{\mathrm{c}}$ & $3.59 \pm 0.02^{\mathrm{b}}$ & $91.60 \pm 0.10^{\mathrm{c}}$ & $6.44 \pm 0.15^{\mathrm{d}}$ & $3.59 \pm 0.12^{\mathrm{d}}$ & $0.42 \pm 0.03^{\mathrm{bc}}$ \\
\hline F4 & $175.00 \pm 0.10^{\mathrm{f}}$ & $30.36 \pm 0.12^{\mathrm{c}}$ & $471.00 \pm 0.02^{\mathrm{f}}$ & $3.66 \pm 0.07^{\mathrm{a}}$ & $77.29 \pm 0.09^{\mathrm{f}}$ & $6.49 \pm 0.15^{\mathrm{d}}$ & $3.35 \pm 0.06^{\mathrm{e}}$ & $0.52 \pm 0.05^{\mathrm{a}}$ \\
\hline F5 & $185.00 \pm 0.05^{\mathrm{e}}$ & $27.35 \pm 0.03^{\mathrm{e}}$ & $484.20 \pm 0.11^{\mathrm{e}}$ & $3.49 \pm 0.15^{\mathrm{c}}$ & $89.70 \pm 0.15^{\mathrm{d}}$ & $6.67 \pm 0.15^{\mathrm{b}}$ & $3.92 \pm 0.09^{\mathrm{b}}$ & $0.40 \pm 0.02^{\mathrm{bc}}$ \\
\hline F6 & $191.50 \pm 0.12^{\mathrm{d}}$ & $29.61 \pm 0.15^{\mathrm{d}}$ & $486.50 \pm 0.07^{\mathrm{d}}$ & $3.58 \pm 0.09^{\mathrm{b}}$ & $87.54 \pm 0.12^{\mathrm{e}}$ & $5.54 \pm 0.05^{\mathrm{c}}$ & $3.61 \pm 0.03^{\mathrm{d}}$ & $0.42 \pm 0.12^{\mathrm{bc}}$ \\
\hline
\end{tabular}

Values are means of three replicates $\pm \mathrm{SD}$, on dry weight basis. 


\subsection{Sensory Evaluation}

Sensory quality evaluation is under taken to gain better insights on the behavior of complex mechanisms in a food product (Kemp et al., 2011). For marketing purpose, results on sensory quality evaluation are of value, because they give in-depth in sight with regard to product preference and acceptability. Table 6 shows results of sensory quality evaluation. Results show that bars with extruded wheat scored highest in colour, taste, appearance and overall acceptance. While bars with extruded rice-wheat scored highest in both colour and texture. As for bars with a mixture of cereals scored the lowest in all parameters. The result show that date bars with wheat, wheat-barley and wheat-rice had the highest acceptability, while the mixture of all had the lowest acceptability.

Table 6. Sensory Evaluation of Different Date Bars

\begin{tabular}{|l|c|c|c|c|c|c|}
\hline & Odour (9) & Colour (9) & Taste (9) & Texture (9) & Appearance (9) & Overall (9) \\
\hline Control & $7.90 \pm 0.07^{\mathrm{c}}$ & $7.91 \pm 0.05^{\mathrm{b}}$ & $8.79 \pm 0.01^{\mathrm{a}}$ & $8.19 \pm 0.07^{\mathrm{c}}$ & $8.94 \pm 0.02^{\mathrm{a}}$ & $8.55 \pm 0.04^{\mathrm{a}}$ \\
\hline F1 & $8.27 \pm 0.03^{\mathrm{b}}$ & $8.47 \pm 0.05^{\mathrm{a}}$ & $8.75 \pm 0.08^{\mathrm{a}}$ & $8.55 \pm 0.02^{\mathrm{a}}$ & $8.96 \pm 0.09^{\mathrm{a}}$ & $8.52 \pm 0.06^{\mathrm{a}}$ \\
\hline F2 & $7.92 \pm 0.08^{\mathrm{c}}$ & $7.95 \pm 0.02^{\mathrm{b}}$ & $7.50 \pm 0.06^{\mathrm{c}}$ & $8.17 \pm 0.04^{\mathrm{c}}$ & $8.90 \pm 0.05^{\mathrm{ab}}$ & $8.45 \pm 0.03^{\mathrm{b}}$ \\
\hline F3 & $7.80 \pm 0.06^{\mathrm{de}}$ & $7.92 \pm 0.04^{\mathrm{b}}$ & $7.60 \pm 0.05^{\mathrm{b}}$ & $8.25 \pm 0.08^{\mathrm{b}}$ & $8.92 \pm 0.02^{\mathrm{a}}$ & $8.50 \pm 0.04^{\mathrm{a}}$ \\
\hline F4 & $8.92 \pm 0.02^{\mathrm{a}}$ & $7.91 \pm 0.01^{\mathrm{b}}$ & $7.67 \pm 0.03^{\mathrm{b}}$ & $8.58 \pm 0.03^{\mathrm{a}}$ & $8.89 \pm 0.08^{\mathrm{b}}$ & $8.53 \pm 0.09^{\mathrm{a}}$ \\
\hline F5 & $7.83 \pm 0.05^{\mathrm{d}}$ & $7.25 \pm 0.03^{\mathrm{c}}$ & $6.93 \pm 0.04^{\mathrm{e}}$ & $5.12 \pm 0.06^{\mathrm{e}}$ & $6.75 \pm 0.01^{\mathrm{c}}$ & $6.59 \pm 0.02^{\mathrm{c}}$ \\
\hline F6 & $7.77 \pm 0.01^{\mathrm{e}}$ & $7.00 \pm 0.08^{\mathrm{d}}$ & $7.14 \pm 0.02^{\mathrm{d}}$ & $6.53 \pm 0.05^{\mathrm{d}}$ & $6.79 \pm 0.04^{\mathrm{c}}$ & $6.25 \pm 0.08^{\mathrm{d}}$ \\
\hline
\end{tabular}

\subsection{Expected Nutritional Contributions of Date Bars in Children Diet}

The amount of crude protein is too low to be considered as a vital source of protein. However, in the date fruit bar, higher protein levels recorded can be attributed to the addition of sesame seeds and different cereals.

Table 7. Expected nutritional contributions of date bars in the human diet

\begin{tabular}{|l|c|c|c|c|c|c|c|c|}
\hline & \multicolumn{5}{|c|}{ Children 4-8 } & \multicolumn{4}{c|}{ Children 9-13 } \\
\hline & $\begin{array}{c}\text { Protein } \\
(19 \mathrm{~g} / \mathrm{d})\end{array}$ & $\begin{array}{c}\mathrm{Fe} \\
(10 \mathrm{mg} / \mathrm{d})\end{array}$ & $\begin{array}{c}\text { Zn } \\
(5 \\
\mathrm{mg} / \mathrm{d})\end{array}$ & $\begin{array}{c}\text { Ca } \\
(800 \mathrm{mg} / \mathrm{d})\end{array}$ & $\begin{array}{c}\text { Protein } \\
(34 \mathrm{~g} / \mathrm{d})\end{array}$ & $\begin{array}{c}\text { Fe } \\
(8 \\
\mathrm{mg} / \mathrm{d})\end{array}$ & $\begin{array}{c}\text { Zn } \\
(8 \\
\mathrm{mg} / \mathrm{d})\end{array}$ & $\begin{array}{c}\text { Ca } \\
(1300 \\
\mathrm{mg} / \mathrm{d})\end{array}$ \\
\hline Control & 45.26 & 72.90 & 66.60 & 3.99 & 25.29 & 91.13 & 41.63 & 2.46 \\
\hline F1 & 60.11 & 65.00 & 66.60 & 4.03 & 33.59 & 81.25 & 41.63 & 2.48 \\
\hline F2 & 59.21 & 63.70 & 77.00 & 4.59 & 33.09 & 79.63 & 48.13 & 2.83 \\
\hline F3 & 59.37 & 64.40 & 71.80 & 4.31 & 33.18 & 80.50 & 44.88 & 2.65 \\
\hline F4 & 53.95 & 64.90 & 66.60 & 3.92 & 30.15 & 81.13 & 41.63 & 2.41 \\
\hline F5 & 53.11 & 66.70 & 78.40 & 3.54 & 29.68 & 83.38 & 49.00 & 2.18 \\
\hline F6 & 52.37 & 65.10 & 72.20 & 4.02 & 29.26 & 81.38 & 45.13 & 2.47 \\
\hline
\end{tabular}

Percentages of the recommended dietary allowances (\%RDA) provided from date snack bars for children (4-8 years and 9-13 years). All nutritionists emphasize the need for a variety of vegetables and fruits in diets as well as grains to ensure an adequate intake of micronutrients.

The expected nutritional contribution of date bars to the children's diet was calculated by taking into consideration the average protein and micronutrients contents of different date bar samples. The calculations for the protein and energy contributions 
of date bars as a percentage of the Dietary Reference Intakes (2005) in the diets of various age groups are presented in Table 7. The data presented in this table show that date bars can contribute significantly to meet a major part of the energy, protein and some important mineral requirements of children.

\section{CONCLUSION}

The study verified that dates, sesame seeds and extruded cereals can be used to prepare date based protein enriched fruit bars of good sensory and nutritional value which provide substantial amount of carbohydrates, proteins, fats, dietary fiber and minerals for children.

\section{REFERENCES}

1. Al-Farsi, M. 2003. Clarification of date juice. International Journal of Food Science and Technology, 38, 241-245.

2. Al-Farsi, M., Alasalvar, C., Al-Abid, M., Al-Shoaily, K., Al-Amry, M., and Al-Rawahy, F. (2007). Compositional and functional characteristics of dates, syrups, and their by-products. Food Chemistry, 104(3), 943-947.

3. Al-Hooti S, Sidhu JS, Al-Otaibi J, Al-Ameeri H andQabazard H. 1997. Date bars fortified with almonds, sesame seeds, oat flakes and skim milk powder. Plant Foods Hum Nutr.;51(2):125-35.

4. Aliani, M., Ryland, D. and Pierce, G. N. 2011. Effect of flax addition on the flavor profile of muffins and snack bars. Food research international, 44(8), 2489-2496.

5. AOAC (2005) Official Methods of Analysis of the Association of Official Analytical Chemists.18th Edition, Washington DC.

6. Dietary Reference Intakes (2005). This report may be accessed via www.nap.edu

7. Gadade, B. V.; Kachare, D. P.; Satbhai, R. D. and Naik, R. M. 2017. Nutritional Composition and Oil Quality Parameters of Sesame (Sesamumindicum L.) Genotypes. INTERNATIONAL RESEARCH JOURNAL OF MULTIDISCIPLINARY STUDIES, 3(7), 1-13.

8. Ghnimi, S., Umer, S., Karim, A., and Kamal-Eldin, A. 2017. Date fruit (Phoenix dactylifera L.): An underutilized food seeking industrial valorization. NFS Journal, 6, 1-10.

9. Hatcher, D. W.; Lagasse, S.; Dexter, J. E.;Rossnagel, B. and Izydorczyk, M. 2005. Quality Characteristics of Yellow Alkaline Noodles Enriched with Hull-less Barley Flour 1. Cereal Chem., 82(1), 60-69.

10. James, C.S. 1995. General Food Studies. In: Analytical Chemistry of Foods, Blachie Academic and Professional, London, New York, Tokyo, Chapter 6, p 135. 
11. Kemp, S., Hollowood, T. and Hort, J. 2011. Sensory evaluation: A practical handbook (pp.12-20) U.K.: John Wiley and Sons.

12. Larmond E. 1994. Is sensory evaluation a science? Cereal Foods World 39(11/12):804-806.

13. Moawad, S.S. and Al-Ghamdi, F.F. 2013. Susceptibility of some dry date cultivars to infestation by Oryzaephilussurinamensis (L.)(Coleoptera: Silvanidae). American Journal of Experimental Agriculture, 3, 651-663.

14. Nadeem, M.; Muhammad Anjum, F.; Murtaza, M.A. and Mueen-UD-Din, G. 2012. Development, characterization, and optimization of protein level in date bars using response surface methodology. Sci.World J. 1, 1-10.

15. Parn, O. J., Bhat, R., Yeoh, T. K., and Al-Hassan, A. A. 2015. Development of novel fruit bars by utilizing date paste. Food Bioscience, 9, 20-27.

16. Sharifi, M., Bashtani, M., Naserian, A., and Farhangfar, H. 2017. Determination of chemical composition, mineral content, antioxidant capacity and rumen degradability in various varieties of wasted date palm. Italian Journal of Animal Science, 1-8.

17. SPSS. 2000. Statistical package for Social Sciences. SPSS for Windows, Version 10, SPSS Inc., Chicago, IL, USA.

18. Sun-Waterhouse, D., Teoh, A., Massarotto, C., Wibisono, R. and Wadhwa, S. 2010. Comparative analysis of fruit-based functional snack bars. Food Chemistry, 119, 1369-1379.

19. Symons, L and Brennan, C.S. 2004. The effect of barley Beta-glucan fiber fractions on starch gelatinization and pasting characteristic. J. Food Sci., 69(4), 257-261. 


\title{
انتاج بارعالى القيمة الغذائية من خامات محلية
}

\author{
حنان عبد الحميد حسين ، ايمان محمد سالم ، محمد رمضان محمد مسعود \\ مركز البحوث الزراعية - معهد بحوث تكنولوجيا الأغذية
}

فى مصر يعتبر التمر محصو لا استراتيجيا وتحتل مصر المركز الاول عالميا فى انتاج التمور حيث

يقدر انتاجها السنوي بحوالى 1,0 مليون طن. ومن المعروف ان التمر يحتوي على نسبة عالية من الند السكريات وينتج العديد من المنتجات من لتناسب رغبات المستهلكين. تهدف هذه الدراسة الدئ الى انتاج

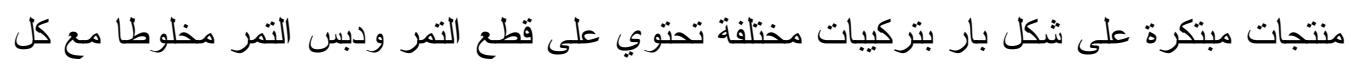

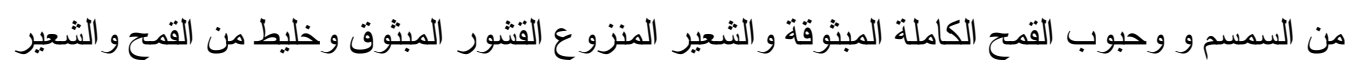
المبثوق و وخليط القمح و الارز المبثوق و الذرة المبثوق و خلطات مختلفه منها وتم عمل تلك الخلطات

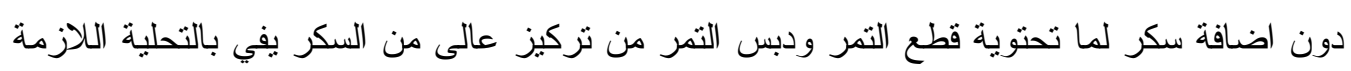
للبار ، تم عمل التحليلات المختلفة للبار الناتج من الخلطات المختلفة من تقدير التركيب الكيميائي و التقييم • الحسي

وقد اوضحت النتائج ان بار التمر بالخلطات المختلفة كان غني بالبروتين و الكربو هيدر ات والدهون

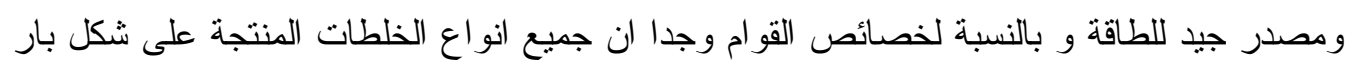

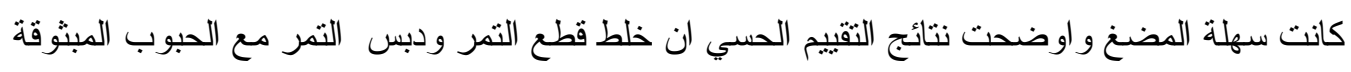
على شكل بار كانت مقبولة بشكل كبير من المحكمين. ومن تلك النتائج يوصي ان ينت انتاج البار

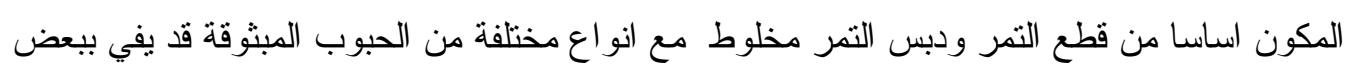
الاحتياجات الصحية للمستهلكين سو اء اطفال او بالغين لنين 